\title{
WRITING KAKAWIHAN \\ AS A LOCAL WISDOM'S TEACHING MATERIAL IN GRADE VII SMPN 3 Cianjur
}

\author{
Tita Herdila \\ Universitas Suryakancana Cianjur \\ titaherdila@gmail.com
}

\begin{abstract}
This paper is motivated by the lack of students' interest in learning to write poetry and lack of interest in literature. In addition, teaching materials based on local wisdom are still rarely used in learning Indonesian. In connection with this, this paper will describe the utilization of the skills and abilities of students in writing poetry. The method used in the research is descriptive. The research technique used is content analysis, interviews, and tests. Based on the results of the study, it can be seen that the average value of kakawihan's poetry writing ability in class VII of SMP N 3 Cianjur is 77.9 is in a good category with 76-85 mastery interval. The highest score of students in writing kakawihan poetry is 87 obtained by one student (4\%), and the lowest value is 73 obtained by 5 students (20\%). Thus, kakawihan kaulinan barudak can be used as teaching material in learning Indonesian language based on local wisdom.
\end{abstract}

Keywords: writing poetry, kakawihan kaulinan barudak

\section{PENDAHULUAN}

Budaya Sunda dikenal dengan budaya yang menjunjung tinggi sopan santun. Pada umumnya, karakteristik masyarakat Sunda seperti yang dapat ditemukan dalam Wikipedia adalah periang, ramah tamah, someah dan saling menghormati. Kebudayaan Sunda memiliki ciri khas tertentu yang membedakannya dari kebudayaan lain. Seperti dalam pameo silih asih, silih asah dan silih asuh; saling mengasihi (mengutamakan sifat welas asih), saling menyempurnakan atau memperbaiki diri (melalui pendidikan dan berbagi ilmu), dan saling melindungi (saling menjaga keselamatan).

Selain itu, budaya Sunda memiliki beragam kesenian, salah satunya bentuk tradisi lisan berupa kakawihan kaulinan barudak lembur (selanjutnya disebut KKBL).

KKBL merupakan sastra lisan yang diwariskan secara turun-temurun. Ketika masyarakatnya sudah jarang menyanyikan, keberadaannya mudah terhapus dan tergantikan. Padahal, melantunkan kakawihan merupakan salah satu cara agar tradisi lisan tetap hidup di tengah masyarakat. Selain itu, dengan memahami isi lagu kaulinan barudak, pembaca akan mengenal adat kebiasaan dan atau pantangan-pantangan yang berada di Sunda.

Seperti yang diungkapkan oleh Sopiah (2017: 222) bahwa dalam kawih kaulinan barudak lebih banyak mengandung nilai yang termasuk ke dalam jenis nilai yang tidak tertulis seperti manusia tidak boleh mudah putus asa, manusia harus rendah hati, manusia harus mampu hidup dengan baik di lingkungannya, manusia harus gigih, manusia harus menjauhi dan tidak melakukan keburukan dalam hidupnya.

Akan tetapi, nilai yang terkandung dalam KKBL yang demikian baik itu kini kurang diminati generasi muda sebagaimana mereka tidak berminat terhadap sastra secara 
umum. Minat generasi muda terhadap sastra semakin hari semakin berkurang karena minat mereka terhadap membaca yang juga kurang. Minat dan kemampuan masyarakat kita dalam membaca bahasa Indonesia tergolong rendah, terutama dalam membaca sastra termasuk di dalamannya jenis sastra yang disebut KKBL. Oleh karena itu, perlu adanya kesadaran akan pelestarian sastra yang hidup di tengah masyarakat.

Melalui pendidikan di sekolah, sastra daerah kembali diperkenalkan. Dengan mempelajari sastra daerah dapat melatihan keterampilan peserta didik dalam bersastra. Salah satu keterampilan yang penting dalam pemertahanan sastra yaitu dengan menulis. Akan tetapi, dalam kegiatan menulis, daya kreativitas peserta didik masih sangat kurang karena dipandang sebagai sesuatu yang sulit untuk dilakukan sehingga menjadi faktor penghambat dalam penuangan ide atau gagasan. Oleh karena itu, minat peserta didik menjadi sangat minim dan cenderung menghindari kegiatan menulis terutama dalam menulis puisi. Untuk meningkatkan kemampuan menulis puisi, seseorang memerlukan sarana pengembangan penalaran dan kekritisan. Sebagai pendukung proses tersebut, penting untuk dipilih kualitas materi yang dijadikan pokok bacaan untuk menambah wawasan dan pengembangan ide yang akan diwujudkan dalam bentuk tulisan.

Sesuai dengan kurikulum 2013 dalam ruang lingkup materi Bahasa Indonesia kelas VII, terdapat materi menulis puisi rakyat. KKBL dapat dijadikan bahan pembelajaran menulis puisi di Sekolah Menengah Pertama untuk meningkatkan keterampilan peserta didik dalam menulis dengan dasar pengetahuan penelaahan struktur KKBL. Dengan demikian, peserta didik dapat mengembangkan ide dan kreativitasnya ke dalam sebuah tulisan serta melestarikan budaya dalam sebuah karya.

Artikel ini akan mendeskripsikan implementasi dari KKBL sebagai bahan ajar menulis puisi dan mendeskripsikan kemam- puan menulis puisi peserta didik kelas VII SMP N 3 Cianjur.

\section{Menulis Puisi (Kakawihan)}

Tarigan (2008: 3) menyatakan "Menulis merupakan suatu keterampilan berbahasa yang bersifat produktif dan ekspresif. Menulis bukanlah keterampilan bawaan, tetapi harus melalui latihan dan praktik yang teratur". Aktivitas menulis apapun jodohnya adalah membaca. Keduanya saling berkaitan karena menulis membutuhkan wawasan dan pengetahuan yang memadai. Dalam pembelajaran menulis puisi kakawihan dibutuhkan sarana yang memadai dan pemilihan bahan ajar yang sesuai.

Sebagaimana puisi pada umumnya, dalam menulis puisi kakawihan pun tidak terlepas dari struktur pembangun kakawihan itu sendiri. Menurut Mustappa (2014: 36), struktur kakawihan biasa disingkat ISIM (imaji, simbol, musikalitas) dan STG (suasana, tema dan gaya bahasa).

\section{Kakawihan Kaulinan Barudak Lembur (KKBL)}

Menurut Hidayat (2013:169), kakawihan disebut juga lagu anak-anak atau kakawihan barudak, sebab bisa dilagukan oleh anak-anak. Umumnya kakawihan erat kaitannya dengan permainan anak-anak (kaulinan barudak). Istilah kakawihan sebenarnya berupa istilah lain dari seni suara. Sekarang dijadikan kajian sastra, sebab umumnya rumpaka kakawihan berupa puisi lama (buhun) mengandung wirahma yang merupakan kombinasi turun naiknya, panjang pendeknya, tinggi rendahnya nada dalam membaca puisi, dan murwakanti yang merupakan kedekatan atau persamaan suara akhir antar kata-kata yang ada dalam sebuah puisi serta memiliki ciri-ciri puisi lainnya. Kakawihan berupa karya anonim, sebab tidak diketahui penulisnya. Penyebarannya turuntemurun dari lisan ke lisan. 
Menurut Tsamyah (1996:42-50), KKBL bisa di klasifikasikan menjadi beberapa golongan: a) wangun paparikan (hompimpah, perepet jengkol, tokecang, tat tit tut); b) kakawihan laraswekas (trang-trang kolentrang, eundeuk-eundeukan lagoni, ucangucang angge); c) kakawihan margaluyu (ayang-ayang gung, oray-orayan, cing ciripit).

\section{METODE}

Metode yang digunakan dalam penelitian ini adalah metode deskriptif analisis, yang merupakan bagian dari penelitian kualitatif. Menurut Sugiyono, (2013:9), penelitian kualitatif adalah penelitian yang berlandaskan pada filsafat postpositivisme, digunakan untuk meneliti pada kondisi objek yang alamiah, di mana peneliti adalah sebagai instrumen kunci, teknik pengumpulan data dilakukan secara triangulasi (gabungan), analisis data bersifat induktif/kualitatif, dan hasil penelitian kualitatif lebih menekankan makna daripada generalisasi.

Metode deskriptif yang digunakan dalam penelitian ini untuk mendeskripsikan implementasi dari Kakawihan Kaulinan Barudak Lembur (KKBL) terhadap pembelajaran sebagai bahan ajar menulis puisi pada peserta didik kelas VII SMP N 3 Cianjur dan mendeskripsikan kemampuan menulis puisi peserta didik kelas VII SMP N 3 Cianjur.

Adapun teknik penelitian yang digunakan yaitu analisis isi, wawancara dan tes. Teknik analisis isi digunakan untuk menganalisis struktur pembangun kakawihan. Teknik wawancara digunakan untuk mendapatkan data kelayakan bahan ajar. Teknik tes digunakan untuk melihat kemampuan siswa dalam menulis puisi kakawihan.

\section{HASIL DAN PEMBAHASAN}

Hasil analisis struktur Kakawihan $\mathrm{Ka}$ ulinan Barudak Lembur (KKBL) diimplementasikan dalam pembelajaran sebagai bahan ajar menulis puisi kakawihan pada peserta didik kelas VII.7 SMP N 3 Cianjur. Bahan ajar yang disajikan berbasis teks dengan tema "Menambah Cita Rasa Bersastra melalui Kakawihan Kaulinan Barudak Lembur". Bahan ajar tersebut terdiri dari empat tugas.

Tugas pertama pembangunan konteks dan pemodelan teks kakawihan kaulinan barudak lembur. Pada tugas ini, peserta didik diberi gambaran mengenai kakawihan kaulinan barudak lembur dan dirangsang dengan beberapa pertanyaan mendasar seputar kakawihan kaulinan barudak lembur. Bentuk pertanyaan yang diberikan yaitu: apakah kalian masih memainkan permainan tradisional $d$ lingkungan tempat tinggal kalian; jenis permainan tradisional apa saja yang kalian ketahui; adakah permainan tradisional yang kalian gemari; bagaimana menurut kalian kondisi permainan tradisional di tengah masyarakat modern.

Tugas kedua, memahami struktur teks kakawihan. Pada tugas ini, peserta didik memahami struktur teks kakawihan dengan menggali informasi, membaca dan memahami struktur kakawihan dari teks yang disediakan. Dengan contoh teks kakawihan beserta struktur yang terdapat di dalamnya membantu pemahaman peserta didik mengenai struktur teks kakawihan.

Tugas ketiga, mengidentifikasi teks kakawihan secara berkelompok. Untuk memperkuat pemahaman peserta didik, disediakan contoh teks kakawihan Cingciripit. Kawihnya sebagai berikut.

Cingciripit

Tulang bajing kacapit

Kacapit ku bulu pare

Bulu pare seuseukeutna

Jol Pa Dalang

Mawa wayang, jrek-jrek nong

Peserta didik ditugaskan untuk menganalisis contoh teks kakawihan tersebut ber- 
dasarkan strukturnya. Kemudian perwakilan setiap kelompoknya membacakan hasilnya di depan.

Tugas keempat, menulis teks puisi kakawihan secara mandiri. Pada tugas ini, peserta didik ditugaskan untuk menulis teks puisi kakawihan berdasarkan jenis dan strukturnya dengan memilih salah satu dari ketiga jenis kakawihan, yaitu jenis wangun paparikan, laraswekas dan margaluyu. Berikut beberapa puisi hasil menulis peserta didik.

Kakawihan Laras Wekas
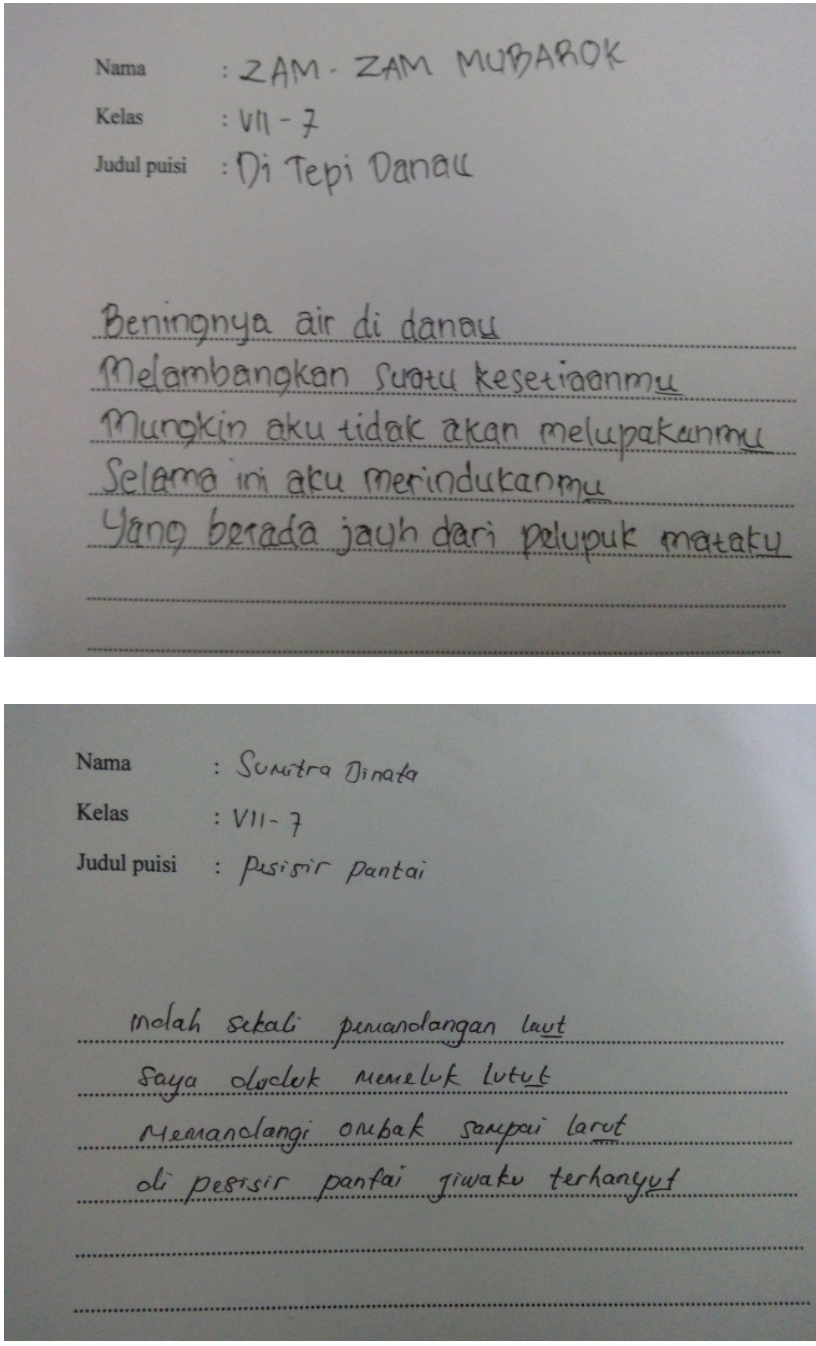

Kakawihan Margaluyu

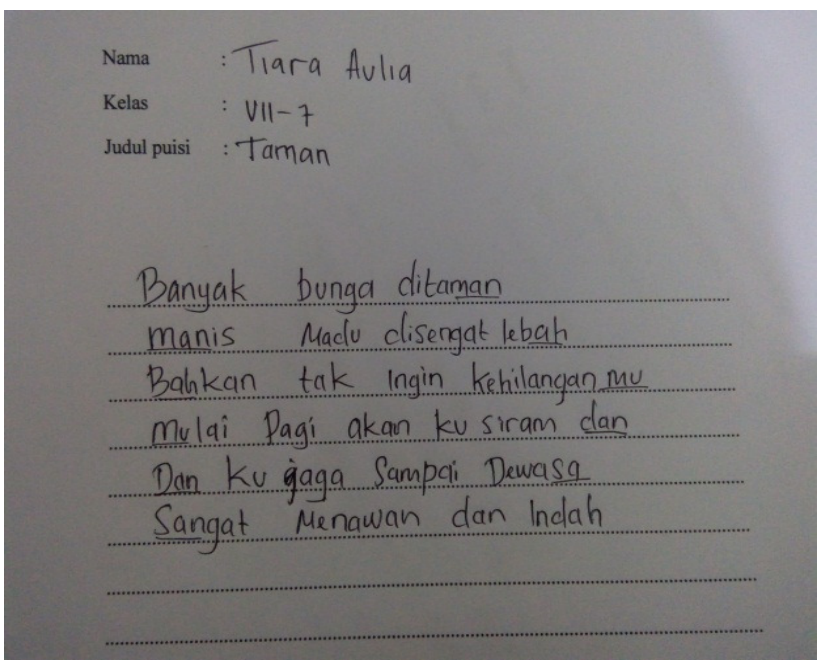

Di dalam bahan ajar menulis puisi kakawihan juga disertai dengan jendela informasi untuk menambah wawasan peserta didik mengenai beberapa istilah yang dianggap asing dan jarang digunakan. Selain itu, disertai juga dengan contoh yang dilengkapi gambar untuk memperindah desain dan menambah daya tarik bagi peserta didik.

\section{Kemampuan Peserta Didik Menulis Puisi Kakawihan}

Berdasarkan hasil tes yang dilakukan pada peserta didik kelas VII.7 Ada beberapa aspek yang menjadi kriteria penilaian kemampuan peserta didik dalam menulis puisi kakawihan yaitu dilihat dari strukturnya yang meliputi ISIM (imaji, simbol, musikalitas) dan STG (suasana, tema dan gaya bahasa).

Pada bagian ini disajikan hasil penilaian terhadap struktur puisi kakawihan. Diketahui nilai peserta didik antara 73 sampai dengan 87, nilai-nilai tersebut adalah nilai akhir hasil dari perhitungan skor peserta didik dikalikan standar nilai (100) dibagi skor ideal (30).

Data selanjutnya dimasukkan ke dalam tabel rekapitulasi nilai untuk menentukan nilai rata-rata, frekuensi, dan persentase nilai mulai dari nilai tertinggi sampai dengan nilai terendah. Secara lebih jelas rekapitulasi nilai yang dimaksudkan sebagai berikut. 
Peserta didik yang mendapat nilai 87 berjumlah 1 orang (4\%). Artinya, puisi yang ditulis oleh peserta didik mendapat skor 26 dari skor ideal 30 berdasarkan struktur puisi kakawihan dan berada dalam kategori baik sekali. Peserta didik yang mendapat nilai 83 berjumlah 4 orang (16\%). Artinya, puisi yang ditulis oleh peserta didik mendapat skor 25 dari skor ideal 30 berdasarkan struktur puisi kakawihan dan berada dalam kategori baik.

Kemudian, peserta didik yang mendapat nilai 80 berjumlah 3 orang (12\%). Artinya, puisi yang ditulis oleh peserta didik mendapat skor 24 dari skor ideal 30 berdasarkan struktur puisi kakawihan dan berada dalam kategori baik. Peserta didik yang mendapat nilai 77 berjumlah 12 orang (48\%). Artinya, puisi yang ditulis oleh peserta didik mendapat skor 24 dari skor ideal 30 berdasarkan struktur puisi kakawihan dan berada dalam kategori baik. Peserta didik yang mendapat nilai 73 berjumlah 5 orang (20\%). Artinya, puisi yang ditulis oleh peserta didik mendapat skor 22 dari skor ideal 30 berdasarkan struktur puisi kakawihan dan berada dalam kategori cukup.

Berdasarkan data di atas diketahui bahwa nilai rata-rata kemampuan peserta didik dalam menulis puisi yakni 77,9 nilai tersebut terlihat pada kemampuan menulis puisi kakawihan. Artinya, kemampuan peserta didik dalam menulis puisi berada dalam kategori baik dengan rentang nilai 76-85. Dari jumlah total peserta didik 25 orang, yang mencapai prestasi belajar baik sekali berjumlah 1 orang (4\%), sedangkan yang mencapai prestasi belajar baik berjumlah 19 orang $(76 \%)$ dan yang mencapai prestasi belajar cukup berjumlah 5 orang (20\%).

Berdasarkan capaian prestasi belajar peserta didik dalam menulis puisi kakawihan, dapat disimpulkan bahwa pemanfaatan KKBL dalam pembelajaran menulis puisi sangat berguna serta dapat menunjang keberhasilan belajar. Sebagaimana penelitian yang dilakukan oleh Siti Sopiah (2017), dalam lagu Kulinan Barudak dapat dijadikan sebagai media dalam bahan ajar pembelajaran bahasa Indonesia, dibuktikan dengan analisis dari seluruh (17) lagu yang diuji menggunakan teori Audrey dan Howard dalam Hidayat (2001:93) lagu Kaulinan Barudak memenuhi empat kriteria bahan ajar yang artinya nilai etika lirik lagu Kaulinan Barudak sangat sesuai dengan media untuk bahan ajar dalam pembelajaran bahasa Indonesia yang mengusung kearifan lokal yang berada di daerah setempat.

\section{SIMPULAN}

Berdasarkan hasil pembelajaran dan tes pada siswa dalam menulis puisi kakawihan, dapat diketahui nilai rata-rata kemampuan menulis puisi kakawihan di kelas VII SMP N 3 Cianjur yaitu 77,9 berada dalam kategori baik dengan interval tingkat penguasaan 7685. Nilai tertinggi siswa dalam menulis puisi kakawihan yaitu 87 berjumlah satu orang (4\%), dan nilai terendah yaitu 73 berjumlah 5 orang (20\%). Mayoritas kemampuan peserta didik dalam menulis puisi kakawihan mencapai kategori baik dengan interval tingkat penguasaan 76-85.

Dengan demikian, kakawihan kaulinan barudak dapat dimanfaatkan sebagai bahan ajar dalam pembelajaran bahasa Indonesia dengan berbasis kearifan lokal.

Berdasarkan hasil penelitian dan simpulan, maka diajukan beberapa saran bagi berbagai pihak. Bagi guru, dapat dijadikan referensi dalam melanjutkan dan mengembangkan bahan ajar yang inovatif dan kreatif. Bagi peserta didik, dapat dijadikan referensi dalam menambah wawasan mengenai bahan ajar berbasis kearifan lokal. Selain itu dapat menumbuhkan rasa cinta terhadap budaya sendiri dengan cara mempelajarinya dalam upaya melestarikan budaya bangsa. Bagi peneliti selanjutnya, hasil penelitian ini dapat dijadikan referensi atau pijakan dalam mengembangkan penelitian selanjutnya. 


\section{DAFTAR PUSTAKA}

Hidayat, Rachmat Taufiq, dkk. 2013. Peperenian Urang Sunda. Bandung: Kiblat Buku Utama.

Mustappa, Abdullah. 2015. Wirahma Sajak. Jakarta: Pustaka Jaya.

Sopiah, Iis Siti. 2017. "Nilai Etika Dalam Kumpulan Lagu Kaulinan Barudak Di Daerah Sunda”. Dalam Jurnal DIKSATRASIA [online], volume 1 (2), 5 halaman.Tersedia: https://jurnal.unigal.ac.id/index.php/diksatrasia/article/view/603/501. [19 Januari 2018]

Sugiyono. 2013. Metode Penelitian Kuantitatif Kualitatif dan R\&D. Bandung: Alfabeta.

Tarigan, Henry Guntur. 2008. Menulis sebagai Keterampilan Berbahasa. Bandung: Angkasa Bandung.

Tsamyah, Budi Rahayu, dkk. 1996. Pangajaran Sastra Sunda Pikeun Siswa SD, SLTP, SMU jeung Umum. Bandung: CV.PUSTAKA SETIA. 